\title{
Multiculturalism in South Africa: Dislodging the Binary between Universal Human Rights and Culture/Tradition
}

\author{
Amanda Gouws \\ Department of Political Science \\ University of Stellenbosch \\ South Africa \\ ag1@sun.ac.za
}

\section{Introduction}

Grappling with the notion of "culture" and multiculturalism in post-colonial societies that have accepted liberal democratic frameworks very often lead to interpretations that pose culture and universal rights as a binary opposition, with culture being related to pre-modern "ways of life" and practices, and universal human rights to modernity, individualism and enlightenment. Due to colonial interpretation of the culture of colonial subjects in Africa there is a (Western) perception that indigenous culture is pre-modern and "backward". This perception is often based on the gendered nature of issues that arise and challenge liberal individualism. The treatment of women and the control of women's sexuality are viewed as core elements of traditional patriarchal and sexist practices.

The aim of this paper is to show how this binary opposition of culture and rights leads to a closure of the discourse about culture and rights and is particularly damaging in post-colonial societies where the misrecognition of cultural practices have a particularly negative impact for women because of its redistributional effect. By applying Nancy Fraser's concept of recognition and redistribution to the debate on customary law and land in South Africa I want to show the complexity of gender relations in "multicultural" contexts in post-colonial societies and secondly attempt to find ways of dealing with the conflict of rights and culture in a more productive way.

\section{Invoking the Cultural Defence}

What has prompted my interest in the culture vs universal rights debate is an increasing use of the "cultural defence" by political leaders in South Africa to justify certain behaviour with regards to women when this behaviour may blatantly be violating gender equality and women's rights.

During President Zuma's rape trial in 2005 (a trial that was in a sense the "culturalization of politics") he has argued that "in his culture" a man cannot leave an aroused woman, he has to satisfy her. He invoked culture to justify non-consensual sex.

Recently Chief Mandla Mandela (Nelson Mandela's grandson) has justified the abduction of underage girls into marriage (called Ukhutwala) as a cultural practice. And an ANC MP Patekile Holomisa, who is also the head of the Congress of Traditional Leaders (CONTRALESA) has argued that the "great majority" of South Africans did not want the rights of gays and lesbians to be protected. He argued that homosexuality in African culture is a condition that could be cured by a sprititual healer (News Now, 17 May 2012). 
In all the mentioned cases above there was an outcry from human rights groups, women's organizations and non-governmental organizations working with women and children, that these utterances undermine the Constitutional rights of women and children, as well as the protection of sexual orientation under the Constitution. It firmly lodged the binary logic of culture vs rights in place. And as Volpp (2001) rightly asks is "why this binary discourse so frequently structures the parameters of the debate?" We also need to understand the debate within the context of specific multicultural societies and how to deal with this binary without attacking culture.

\section{Does the concept of multiculturalism travel?}

The notion of multiculturalism in Western contexts most often relates to minority cultural groups residing in Western democracies and the extent of their ability to practice their indigenous cultures without undermining universal human rights. Immigration of people from the developing world to Western societies has fuelled this debate in the past two decades where rather homogeneous societies have become "multicultural" due to migration. The discourse of multiculturalism became an attempt in these societies to deal with cultural differences. But as Phillips and Saharso (2008: 291) point out multiculturalism is in crisis and was, more or less, attacked from its inception and was never adopted as official policy anywhere in Europe. At the centre of the retreat from multiculturalism have been the rights of women and challenges to the misogynistic practices of minority cultures, as a contravention of the core value of gender equality in democracies. As they put it (p295):

The endorsement of gender equality as a defining feature of European polities is, at one level, very much to be welcomed. When, however, the rights of women feature as a marker of a modern liberal society, one of the key things differentiating such societies from 'traditional', non-Western illiberal ones (sic), this encourages a stereotypical contrast between western and non-western values, and represents (all) migrants as less likely than those long established in Europe to accept the equality of the sexes.

Multiculturalism is not a concept that travelled well to South Africa. It is viewed as Western in its origin and is jarring in post-colonial societies that are very often multi-ethnic or have been coerced to give up parts of their culture and identities due to colonialism, or whose culture has become reified due to colonial interference. Furthermore, it is a concept that pits groups rights against the rights of individuals ${ }^{1}$.

The concept "multiculturalism" is not widely used in South Africa, given its connotation with Western societies. The more widely used concept it that of cultural pluralism, linked to the apartheid history that segregated ethnic groups according to ethnic identities and language (language was often used as a proxy for ethnic identity). Under apartheid ethnic differences were overshadowed by race, since race was the common denominator that united black ethnic groups against the apartheid government and its beneficiaries - white Afrikaners, white English speakers and the two "in between" groups - mixed race or colored people and Indians.

\footnotetext{
${ }^{1}$ See eg van der Merwe's (1996) reflection on the multicultural condition in South Africa.
} 
Yet, since 1994 under liberal democracy that removed social and territorial segregation in South Africa, the country has become a multicultural society and is becoming more so with thousands of Africans from other African countries flocking to South Africa. This donning of multiculturalism as a description of the post-Apartheid society can be linked to its acceptance of liberal democracy as the post-apartheid regime, or the liberal moment that catapulted it into a society freed from the bonds segregation. Liberal societies foreground civil liberties and freedom as the key notions of existence, where individualism is supposed to trump cultural ties. The notion of liberal individualism in post-colonial societies where different ethnic groups have strong communal ties, is more difficult to assert than can be accepted at face value because of the construction of the subject under liberalism.

\section{The Construction of the Subject under Liberalism}

Liberalism is not viewed as cultural because of its focus on individuals. Under liberalism we make the distinction between those who are ruled by culture and those who rule themselves but enjoy culture (Brown, 2006). Or as Mamdani (in Brown, 2006: 151) has put it Westerners have culture but for the "Others" - culture has them! The solution to being ruled by culture is liberalism because its deemed universalism makes its cultural claims/ principles invisible.

Under liberalism the subject is constructed as an individual with self-making and selfregulating agency, with rights and equal standing of the law (Brown, 2006: 17). Any person or nation that does not meet these requirements, from the perspective of liberal democracy, is constructed as "other" or "beyond the pale" and as Brown (2006: 151) argues this asymmetry based on the moral autonomy of liberalism and the imagined opposition with culture puts culture in a subordinated position to liberalism.

Liberalism "masters" culture by privatizing and individualizing it, therefore culture becomes individual and privately lived choices (Brown, 2006: 21). Liberalism's focus on the individual juxtaposes it to culture's invocation of groups and the continuity of groups. Culture should be feared because it opposes individual rights and liberties, which are constructed as universal principles, untouched by culture, while those who are viewed as governed by culture have essentialized identities (p34). Through a "sleight of hand" liberalism reduces freedom to rights and equality to equal standing before the law and thereby make many ways in which people are subordinated, marginalized or have inequality bestowed on them, invisible. The liberal subject is constructed as an autonomous individual, with rights who are unfettered by culture (Brown, 2006: 23).

The construction of the liberal subject reinforces the divide between the public and the private sphere because the public sphere that is premised on equality cannot allow for distinctive identities (and therefore difference), so that particularities are considered part of the private sphere (Gressgard, 2010: 33). It is here that most women experience culturally driven subordinations. As Gressgard points out that "others" complaining about unfair treatment may risk being silenced or stigmatized because the premises or equality are defined by the order against which they protest.

In the debate on multiculturalism women as liberal subjects are not bound by the subordination that women experience who are viewed as living in cultural contexts. It 
therefore also hides the other forces besides culture that constructs women's lives, or make them blind for their own oppression that are not ascribe to culture, such as high levels of women's death due to gun violence in the USA (Volpp, 2001: 1181). The claims of liberalism's universalism paint minority cultures as misogynistic, frozen and static (Volpp, 2001: 1191). These subjects are defined by their group based determinism. The construction of the subject that is not governed by liberalism is seen to lack autonomy and their subjectivity is only constructed through gender. The liberal subject stands apart and separate from the particular and the local and inhibits an abstract level of agency (Volpp, 2001: 1199 1201; Gressgard, 2010: 39).

Minority cultures therefore are discursively constructed as confined by their embodiedness and relational ties and therefore not subjects of a liberal society, because their gender subordination is integral to their cultures (Volpp, 2001: 1185). Other markers of women's identity that may repress them such as race or ethnicity are ignored.

This construction of the subject does not allow for difference and can be contributed to the difficulty to account for difference leading to the binary logic of universalism and cultural distinctiveness. This pose women as victims rather than thinking about them also as agents whose agency may be circumscribed by structural forces (such as colonialism, racism, rurality, globalization).

This struggle with women's subjectivity is well illustrated with the debate about feminism and multiculturalism that was started by Susan Moller Okin's question "is multiculturalism bad for women?" 2

Her main concern was the treatment of women by minority cultural groups through what is deemed cultural practices. These practices are very often aimed at controlling the sexuality and reproduction of women. She made the argument that feminists have thought that multiculturalism and feminism will be compatible but it turned out not to be the case, because of intra-cultural practices that are harmful to women and are exercised in the private sphere. In this regard she questioned the notion of group rights for minority groups, when rights are already protected by individual rights in liberal societies (Okin, 1999: 9-24). Okin's main conclusion was that democratic societies cannot tolerate harm done to women and these practices should therefore be outlawed. The dilemma that Okin saw was that one cannot embrace both the values of feminism and multiculturalism at the same time based on the assumption that minority cultures are sexist.

Since this type of analysis is not useful to dislodge the binary I now turn to Nancy Fraser's theory of justice based on redistribution and the recognition (of cultural identities) that will give us a better purchase on how to think about culture in liberal democratic societies.

\section{Recognition/Redistribution}

Gender inequality can be considered a form of injustice that has far reaching consequences for women's access to resources but also to the recognition of their identities. Fraser ( 1998a; 1998b) argues that if we use distribution as a measure then gender is a basic organizing

\footnotetext{
${ }^{2}$ This is also the title of her book that sparked a debate published in the same book. See Okin (1999).
} 
principle of the economic structure of a society that involves the division between paid (productive) labor and unpaid reproductive labor. But if we use recognition as a measure, gender is a status differentiation that privilege traits associated with masculinity and devalue all things coded feminine. This can be considered a devaluation of cultural norms important to women that causes the injustice of misrecognition (Fraser, 1998a: 6). For women there are therefore two dimensions to injustice - that of unequal distribution of resources and that of the misrecognition of cultural norms. In order to deal with both dimensions of injustice we need to change the economic structure and the status order of contemporary society. Misrecognition has to be perceived as a status injury that denigrates femininity, race, sexual orientation and other markers of identity related to "women's status". This misrecognition is also related to the equal right of esteem and respect.

In empirical realities struggles for redistribution and recognition are often connected -for example misrecognition can be a byproduct of maldistribution. Status injuries can lead to distributive injustices (Fraser, 1998a: 8). She rejects the idea of "substantive dualism" where redistribution and recognition are two different spheres of justice - rather, she calls for "perspectival dualism" where redistribution and recognition constitute two analytical perspectives of each domain (economy and culture) (Fraser, 1998: 8). She illustrates her argument with reference to poor people who are in need of social welfare. Means tested benefits for the poor are the most direct way of redistribution but it stigmatizes the recipients as lazy and deviant (Fraser, 1998a: 9). As she observes it adds the insult of misrecognition to the injury of maldistribution. Therefore there should be no redistribution without recognition and no recognition without redistribution.

Fraser (2000) warns against a more recent phenomenon in multicultural societies where recognition struggles have come to displace redistribution struggles, as a form of identity politics. If recognition struggles are not linked to redistributive claims it leads to situations where group identities are reified. This encourages separatism, intolerance, chauvinism, patriachalism and authoritarian tendencies (Fraser, 2000: 108). The problems of displacement and reification are serious because they may lead to the violation of human rights in name of identity politics.

Drawing on Hegelian philosophy she argues that identity developed by recognizing other's identities and by being recognized by others. To be denied recognition leads to a distortion of one's relations to one self and an injury to one's identity. Misrecognition prevents the development of a healthy cultural perspective (Fraser, 2000: 109). The politics of recognition is not identity politics and to equate the two encourages the reification of group identities and the displacement of redistribution.

Reification imposes a single, drastically simplified group identity that is at odds with the complexity of people's lives, their multiple identities and intersectionalities of those identities (Fraser, 2000: 112). The affirmative recognition of identity politics reinforces and reproduces class or race or gender differences, rather than dissolving them. She calls them stigmatizing recognition.

Her solution rejects the model of identity politics and offers a status model in its place. Misrecognition as status harm means a politics that will overcome subordination "by 
establishing the misrecognized party as a full member of society, capable of participating on par with the rest" (p113). Misrecognition is therefore not only a free standing cultural harm but an institutionalized relation of social subordination, eg marriage laws that exclude same sex partnerships as "unnatural". It is a form of systemic status subordination that is a consequence of cultural domination and disrespect.

In order to overcome the problems of both misrecognition and maldistribution Fraser (2007: 27 ) suggest the solution of the "parity of participation", where people can participate in politics and for resources as peers or equals. Therefore we need to take cognizance of parity impeding values that are institutionalized in many different sites - such as law, government policies, administrative codes or professional practice, or institutionalized informally in associational patterns, customs, traditions and practices of civil society. Institutionalized patterns of cultural values constitute some social actors as less than full members of society that can participate as peers. This is an injustice in and of itself (Fraser, 2000: 114). The status model does not allow for only one type of remedy of misrecognition but opens a range of possibilities depending on the context of those who are excluded from the parity of participation. This model therefore offers more than the recognition of identities but relies on institutional remedies for institutionalized injustices and has to be applied at the intergroup level (to assess the impact of institutionalized cultural value between groups, usually minorities and majorities) and also on an intragroup level (to assess the internal effects of minority practices) (Fraser, 2007: 31).

This model takes on board both maldistribution and misrecognition as two distinct dimensions which are concerned with the allocation of disposable resources as well as cultural meanings and norms that may affect the relative standing of social actors (2000: 116).

Unlike the identity model the status model understands social justice as encompassing two analytically distinct dimensions: a dimension of distribution which involves the allocation of disposable resources to social actors and the recognition dimension concerned with the effects of institutionalized meanings and norms on the relative standing of social actors. The parity of participation must satisfy two conditions - that of the independence and voice of participants (Fraser, 2007: 28).

Fraser (2007: 27) argues that there are certain social arrangements that impede the parity of participation - that of institutionalized deprivation, exploitation and gross disparities of wealth that deny status and burden members of communities. In order to relieve this problem of status inequality through political means she added a third dimension to her model, called a political dimension of social justice. This dimension refers to representation that allows for solutions through governance structures and decision making (Fraser and Naples, 2004: 1117).

In post-colonial societies material conditions reinforces the problem of maldistribution and malrecognition. As Fraser (1998a:6) argues kinship regulates marriage and sexuality but because kinship constitutes the overarching principle of redistribution kinship status can determine distribution, where malrecognition can lead to maldistribution. 
If one should apply this model to multicultural conflicts the remedies are related to the different dimensions. For maldistribution what is needed as a remedy is better distribution of material resources, better division of labor and economic inclusion. High levels of inequality in wealth and income and the inability to find employment prevents parity of participation (Stopler, 2007: 319).

For misrecognition what is needed is cultural recognition of the group's difference but not in a way that sets them up against other groups and reify their existence, but also that institutionalized patterns of cultural value presents all groups with respect and achieving social esteem (Stopler, 2007: 319). What is important is that Fraser views misrecognition as institutional, not merely attitudinal. Institutional structures can prevent parity of participation and esteem. Changing institutional discrimination is a matter of social justice.

A lack of political representation may need a change in groups under representation or lack of ability to gain or access political power. When representation is rectified it may lead to changes in both maldistribution and misrecognition.

Stopler (2007:310-311) makes the important point that multicultural claims need to be contextualized. As she puts it:

...multicultural claims should be analysed in the political, social and economic context in which they are made and should not be detached from or given precedence over other dimensions of justice. Nevertheless, many times claims of discrimination by cultural, ethnic or religious minorities, and their claims for special accommodation are perceived solely as claims for recognition or as claims invoking the right to culture, and are debated without properly examining the social context within which they are made or the political and economic circumstances that surround them.

Stopler is correct in this regard but I want to extend the argument to African post-colonial context where multiculturalism very often are claims by indigenous populations against liberal democratic political systems that have erased their histories, especially around the issues of land possession. The claims therefore represent the economic dimension of redistribution of land and therefore livelihoods), the cultural dimension that is the recognition of customs and traditions (very often these are romanticised ideas about a pre-colonial past) and political - to be represented in the liberal democratic political system. Here intergroup and intragroup maldistribution and malrecognition becomes a feature of the political context.

Fraser has been widely criticized for not including a political dimension to arguments (this was included in her later work). The question that needs to be posed is who are the actors of the maldistribution and the misrecognition? This does not happen a vacuum but are very often happens through conditions constructed by the state. The silence on the state and the political on Fraser's part needs closer scrutiny. As Feldman (2002: 410) argues the difficulty is that it reflects some broader tensions in thinking about the state and civil society as sites of injustice. As he argues the real power are economic relations of exploitation and cultural relations of stigmatization - the critique of the state is missing as a source of oppression and hardship in itself. The state can be a source of affirmation (or rejection) of redistributive 
politics, as well as source of transformation. He applies his arguments to the welfare state. In the South African context it needs to be applied to the post-colonial state.

Feldman (2002: 417) asks whether the state is part of the system that produces maldistribution and socioeconomic injustices, and part of a cultural structure that produces injustices of recognition through certain policies. Or is there an irreducible political dimension to injustice? His concern is that the state "vanishes from view" and as a source of power. He rightly points out that the state produces subjects, as bureaucratized, dependent, disciplined, as well as marginalized and gendered!

The status model makes it possible to merge struggles of recognition with struggles for redistribution because it shifts the focus to institutions. Fraser argues that misrecognition in this regard means the deinstitutionalization of parity-impeding cultural norms. Institutions therefore need to be changed to establish status equality (Dahl et al, 2004: 377).

A further important point made by Fraser is that disrespect that results from the misrecognition of status is that disrespect is not so much attitudinal as it is structural (Dahl et al, 2004: 378). It is in this argument that the third or political dimension of her model becomes crucial - that redistribution and recognition be related to representation. Governance structures and decision making procedures need to be problematized.

It is therefore important that we understand the dynamics of the discourse of rights and culture in post-colonial societies.

\section{The problem with "rights talk and culture talk" in post-colonial societies}

In post-colonial societies the concept "culture" is often viewed with suspicion because as Chanock (2000: 18) points out to think that there are cultural unities in Africa, after centuries of imperialism is a fantasy. He argues that cultures are complex conversations within social formations, and the use of culture needs to be scrutinized for its particular usage and meanings within a particular context.

Culture should be understood as used here as a "common sense" understanding of traditional practices, ways of understanding life and making sense of the world. Practices and customs are important for issues of recognition.

Englund (2004: 9) points out that post-colonial governments in Africa had great difficulties in acknowledging and accommodating difference. The politics of recognition in Africa draws on a preoccupation with human rights that obscures the social and political processes through which the subjectivities are forged. In other word the politics of recognition that claims rights has an aesthetic that makes groups and communities appear as individuals (p11). Therefore the politics of recognition is expressed in the language of rights.

As Englund argues (2004: 12):

Campaigners against violations and abuse are obliged to voice their complaints in the same language in order to be heard. As a result, claims and complaints often develop into a genre in which the indispensable social context is erased, constitutive social relations obliterated...Rights are seen, in fact as the private property of mutually 
dependent individuals and groups. In such representations there is little room for the intersubjectivity (emphasis in the original) underpinnings of victims' subjectivity, for its moral, political and existential grounding...

In Africa where communal or collective identities (such as that of an ethnic group) are primary this poses serious problems for making relationships and connections the starting point of recognition. The politics of recognition revolved around identity politics (Englund, 2004: 12). But most people in Africa have hybrid identities and the solution is located in reaching beyond the discreteness of liberalism. What is needed is a relational aesthetic of recognition that will situate subjects contextually, that will show how they are trying to deal with political and economic positions through relations with others (p14). What needs to be overcome is the hegemonic role of $r$ rights talk in Africa, to show the interdependence in which social relations rather than individuals are primary (p17).

\section{The Construction of Culture under Colonial Conditions}

Under colonial rule the codification of customary law has shifted power from communities to traditional leaders, which made it easier for colonial powers to govern. This has distorted the power of traditional leaders and the complex relationships they have with their subjects.

The distinction that Mamdani (1996) makes between citizen and subject (where citizens enjoy rights and subjects live under customary law) that live in the same social world shows the inequality that makes the politics of recognition take on a specific form in sub-Saharan Africa. It created dichotomized societies of citizens who lived under democratic rule and subjects who lived under customary law. The traditional leaders became complicit with colonial power in the invention of culture through the arbitrary nature of how customary law was codified and dispensed.

The colonial discourses that have been constructed around customary law are profoundly gendered. The gendered organization of power held by the traditional leaders is so pervasive that it has become invisible. As Chanock (1991: 55) has remarked African law can and will contain not a reflection of culture but a political process. In the process of inventing legal knowledge around customary law colonial power preferred rigid rules (Chanock, 1991: 57).

In resisting these "invented" customary law "defensive customary law" was constructed during the historical process of interaction with colonial rule (Nhlapo (1995: 161). This was an official version of African customs that arose as a result of destabilising social and political changes, and also in response to them. Defensive customary law represented an alliance between colonial authorities and African male elders who controlled land and cattle, as well as women and children. This construction led to rigid legal rules that replaced more fluid and context driven customs, or living customary law, and entrenched colonial dominance.

The negative consequences of defensive customary law for women have included the reinforcement of patriarchal norms, bestowing superior status and power on senior males, the entrenchment of patriarchal bias through distortion of customs and a more rigid division between the public and private sphere (Nhlapo, 1995: 162). Some of the most serious distortions arose around access to land. Men were granted property-holding capacity that placed women outside the law. The male head of the household became the only true person 
in law, while women were treated as perpetual minors. It gave senior males the power to create culture and to essentialize and institutionalize a diverse range of practices followed in communities (Chanock, 2000: 21).

Nhlapo (2000: 144) argues that there is a problem inherent in "rights talk" because it is suspicious of culture, and culture is always scrutinized by the privilege in society, so that it is shown to be opposed to individual rights. Criticism of culture can be used to legitimise pressure on indigenous communities to change. He asks whether this is a sincere attempt to make multiculturalism work or a resistance to living with cultural variation?

Family law and land law are the most often invoked as falling into the realm of culture. As Chanock, 2000: 34) argues both family and land law regulate the structural building blocks of rural societies. Land is necessary for subsistence farming to sustain subordinated peasantries. When people become threatened by the loss land and family support, the need to claim land as culturally embedded becomes the strongest. Yet, enshrining rights in universal rhetorical form at the highest level of law cannot alley the fears and needs of those who are dependent on the sustained cultural claims of land and traditional family forms (Chanock, 2000: 35). These claims may be related to marriage and separation, divorce, rights and duties to children, division of property and inheritance as well as duties between generations and kin. These complexities are rarely captured by static law but rather by an understanding of living customary law. Chanock (2000: 34$)$ points out that a reliance on rights jurisprudence has removed the possibilities of justice delivered through a political process and the political arena to a de-politicized set of legal principles.

The way the South African government has tried to deal with customary law that conflicts with the Constitution is through the liberal solution of law reform. I will illustrate these attempts with the contestation around two recent Bills (the Communal Land Rights Bill and the Traditional Courts Bill) that will have a direct impact on women's access to land and land tenure. The issue of the redistribution of land in post-colonial societies is crucial to rectify historical land dispossession (especially in South Africa where Black Africans were only entitled to $14 \%$ of land under apartheid) but it is also crucial to ensure that women get land to carry on subsistence farming. Both bills aim at reforming the Black Administration Act 38 of 1927 and the Black Authorities Act 68 of 1951 in an attempt to deal with traditional leadership within a democratic government (after the distortions of their power due to colonialism and apartheid) (See The Star, 15 May 2012).

\section{The Communal Land Rights Act (CLRA)}

Historically people living under customary land held land communally and the CLRA was aimed at protecting communal land rights, securing indigenous entitlements to land that are legally vulnerable given past discriminatory laws and administrative practices (Claassens and Mnisi, 2011: 94). Most of these laws diminished women's claims and status with regards to land entitlement in relation to men. In the past the strength of the rights were related to individuals and exercised by individuals within families, as opposed to the top down power of tribal authorities or traditional leaders. Claassens and Mnisi, (2011: 94-95) argue that past and current understandings of hierarchical property relations limited the understanding of entitlements of land as overlapping. 
CLRA was set aside by the Constitutional Court for not meeting constitutional requirements, one of the important ones is the equality of women. CLRA continues colonial distortions of land possession by not taking into consideration the family as an institution and the family based nature of land rights under customary law that formalizes land rights on the individual and community level (Claassens and Mnisi, 2011: 95). By giving traditional leaders the right to distribute land, women's customary entitlements to land are once again undermined as it was the case under colonial rule and apartheid. Unmarried rural women living on family land will be the worst affected. Under "old order" rights land are held by men and their wives benefit from the husband's land possession, yet all other categories of women are at a disadvantage - unmarried women, widows, and divorcees, as are unmarried sisters and brothers and orphans, and particularly vulnerable are widows and unmarried women living on family land.

Claassens and Mnisi (2011: 97) also point out that the Act undermines and trumps the local family and village forums in which rights are currently claimed, negotiated, distributed an defended by centralizing power to the traditional councils. The effect of the Act is to bolster patriarchal power, making women's claims less likely to succeed and undermines indigenous accountability mechanisms related to layered decision making around land.

\section{The Traditional Courts Bill}

This Bill also makes no provision for the acknowledgement of decision making and dispute resolution on family and village level. Village Councils as a first line of defence in disputes are ignored (Claassens and Mnisi, 2011: 99). The main problems with the Bill is that women cannot represent themselves in these courts - they have to be represented by male family members, and widows specifically cannot enter the "sacred spaces" of the courts while in mourning and therefore they are the most vulnerable during this time to lose their land if they cannot negotiate for it.

The consultation on the content of the Bill only involved traditional leaders who have a vested stake in the continuation of distorted custom and tradition that confer power on them. The Bill applies to about 17 million people living under customary law, yet even when they do not recognize traditional courts they cannot opt out of its jurisdiction and ask for civil courts to hear their cases This is anathema to restorative justice (LRG, 2012: 10). The jurisdiction of the courts over criminal and personal disputes is very broad with unaccountable powers given to traditional leaders to impose coercive sanctions such as forced labor and there would be no appeals processes (LRG, 2012: 5). Making "senior traditional leaders" the sources of power in traditional courts distorts customary law and exacerbates gender inequality (LRG, 2012: 5). It also denies that family courts are a legitimate part of the traditional court system. As the Bill stands it fails to recognise the full range of traditional courts in operation - family, clan, ward and village councils and meetings (LRG, 2012: 6).

Decentralized power makes it more possible for women to influence living customary law. Women are more able to voice their concerns on lower levels. The Bill will also prevent strong women councillors from emerging (LRG, 2012: 7). 
The bill also prevents women to become agents of the courts but it will make cases of gender based violence and maintenance so much more difficult to place in front of traditional leaders because traditional leaders have to ensure women's participation - so women will have to challenge traditional leaders in order to invoke their rights. This would be very difficult for women to do (LRG, 2012: 14).

Judge (2012) also points out the threat of this bill to lesbian women in the face of traditional leaders being on record opposing same sex marriages, who have repeatedly attempted to get the "sexual orientation" as grounds for non-discrimination removed from the Equality Clause in the Bill of Rights. Traditional leaders also recently spoke out fiercely against the adoption of children by same sex couples. How can lesbian women, represented by men, expect fair hearings in traditional courts if they cannot exit from its jurisdiction?[ http://queery.oia.co.za/2012/04/the-culture-of-the-chiefs-is-a-set-back-for-gender-and-sexualrights/trackback/] (downloaded 20 April 2012).

As the groundswell reaction by women's organizations such as the Women's Legal Centre and the Rural Women's Movement, human rights NGOs and the Commission on Gender Equality attest, this Bill is viewed as a serious infringement of women's equality and human rights.

What are the implications for recognition and redistribution of these laws to deliver justice?

\section{Recognition}

In South Africa 17 million people live under customary law that has not been viewed as on par with Western civil law. The recognition of customs and tradition of people who live under customary law and traditional leadership in South Africa was integral to the process of transition to democracy. When the traditional leaders were not included as a delegation to the negotiation process they formed the Council for Traditional Leaders of South Africa

(CONTRALESA) and insisted on being included. This was accepted but the gendered nature of their inclusion became apparent very quickly. No women formed part of the delegation and their demands did not concern the status of women. The inclusion of CONTRALESA in the negotiation process led to the formation of the Gender Action Committee and the demand for an autonomous Commission on Gender Equality (CGE) (which later included in Chapter 9 of the Constitution), so that women's rights can be championed by the CGE.

What CONTRALESA achieved was the parity of participation to create inter-group recognition for people living under customary law, yet they did not create intragroup equality for women because of the misrecognition of women under customary law.

Until the passage of the Recognition of Customary Marriages Act in 1998 women were considered minors who could only rely on male relatives to make demands on their behalf. Even married women were considered minors and lost all right to movable and immovable property on accounts of the death of their husbands. They had no legal standing. From the perspective of gender equality this is the worst type of exclusion from citizenship rights because it makes invisible the needs of women or their claims to rights and justice, but moreover made them completely subordinate to men (see Gouws, 2004) 
To rectify intragroup inequality there should be recognition of women as agents who should be recognized in law and who should therefore have the status of majors and the agency to act in their own behalf. The Recognition of Customary Marriages Act managed to change women's legal status and to eradicate some of the intra group discrimination (but did not outlaw the bride price or polygamy).

What secured inter group equality was the participatory parity of the traditional leaders who negotiated on behalf of people living under customary law. Customary law was acknowledged but with the conditionality that it should not conflict with the Constitution. In cases of conflict customary law should be harmonised in favour of the Constitution. This negotiation pact therefore allowed space for legal pluralism, as a solution for multi-cultural claims.

Yet, what the case of South Africa shows is that participatory parity of cultural minorities may not lead to intra group equality. The misrecognition of women as agents under customary law has led to maldistribution of benefits for women, even though they now have legal standing.

\section{Redistribution}

Because land and family law are at the centre of the legislation discussed it still views women's agency as connected to male family members. Because of the lack of recognition of women as independent decision makers under customary law it leads to maldistribution of land to women.

A prior act - the Recognition of Customary Marriages Act of 1998 - at least gave women legal standing but it did not change the inheritance regime for women in case of death of their husbands, nor did it change the benefits for women when they got divorce. It was only in the Bhe case $e^{3}$ that the Constitutional Court addressed the issue of inheritance under customary law as leading to women's inequality and in most cases destitution.

In the Constitutional Court's ruling law makers were instructed to change the inheritance regime for women when their husbands die intestate, so that they do not loose land and property. The Bhe case highlights the importance for women of being able to appeal to a higher court when customary law discriminates against them.

\section{Political In/Exclusion}

Fraser's inclusion of a political dimension aimed to relate redistribution and recognition to representation that would allow for the decision making structures and governance procedures to take on board issues of multicultural claims. Inadequate participation in decision making processes can show up the role of the state and political dynamics in the construction of new or additional injustices, in this case for women.

If we rely on Fraser's notion of recognition as one of the recognition of status, rather than identity we can see that in the case of women's access to land under customary law in South

\footnotetext{
${ }^{3}$ See Humonga (2005).
} 
Africa what is needed is the recognition of people's standing as equal partners in social interaction (Dahl et al, 2004: 377).

The widespread critique of the Communal Land Rights Bill as well as the Traditional Courts Bill by women's organizations, legal groups and concerned individuals leads us to problematize the political institution of parliament as well as governance structures of traditional leaders. This is a political dimension of recognition and redistribution that cannot be reduced to the other two.

Women living under customary law have been excluded from a process of consultation of what they want with regard to land tenure. This is not only a misrecognition of their identities but also a negation of their traditional status as women living under customary law. This has far reaching redistribution consequences since women cannot negotiate for land or be present where negotiation may take place. It is common for women to lose access to land, but more so lose their livelihoods and that of their children.

Both these bills passed through the South African parliament with a presence of $45 \%$ women, many of them from the rural areas. The question needs to be asked why they did not object to both bills in a way to stop them from passing through parliament? Participation under customary law is consensus seeking but parliamentary politics is adversarial, with men often ridiculing issues relating to gender. This may silence women. Secondly, there are alliances in the African National Congress (ANC) between men and women in parliament that women may not want to risk. (See Gouws, 2011). The political dimension of the contestation around issues relating to custom and tradition has led to pacts between members of parliament and traditional leaders. One of the reasons for this is that traditional leaders have power over large number of voters under their jurisdiction - support that presidents may need to stay in power (eg President Zuma - who relies on the support of traditional societies). The pacts entrench the power of traditional leaders to the exclusion of women in exchange for electoral support for the governing party.

While the argument for representation is one of the parity of participation, it may not work to the advantage of women in post-colonial societies. Parity of participation needs to include women living under customary law to speak for themselves (giving them voice) in the traditional structures from which they are excluded. Because as Stopler (2007: 319) argues "the objective condition of participatory parity requires that the distribution of material resources be such as to ensure participants' independence and 'voice'". Where social arrangements continue deprivation, gross disparity of income, housing and education they violate the conditions of participatory parity but also of equal opportunity and the achievement of social esteem.

I will now turn to some remedies for the problem of political exclusion.

\section{Remedies for exclusion}

Fraser (1998b: 82) argues that there are two remedies for the injustice brought about by a lack of redistribution or recognition. She calls them "affirmation" and "transformation".

Affirmation refers to measures that will change inequitable outcomes of social arrangements without disturbing the causes of underlying framework that generates them. One example 
would be to re-evaluate devalued group identities and accord them more respect without changing the content of those identities. Transformation, on the other hand, will transform the underlying cultural-valuation structure. As she points out it will change more than raise selfesteem - it will change everyone's sense of belonging and self. For her affirmative recognition remedies contribute in the long run to group differentiation while transformative recognition destabilize them so as also to make room for new identity formation.

As have been indicated earlier the status model of recognition allows for a range of remedies that we can apply to the problem of land and gender inequality under the current legal regime in South Africa. I will now consider exit, autonomy and voice, dignity and respect, and legal pluralism.

\section{Exit}

Women may choose to exit from the jurisdiction of customary law. But as we have seen the Traditional Courts Bill does not allow women to exit because it does not recognize the jurisdiction of civil courts.

Exist may also not be a realistic option as Phillips (2009) has argued. It may demand too much from poor women, so that it will make it an unrealistic option. Poor women from rural areas will have to travel to urban areas to defend their cases in civil courts. They may not be able to negotiate their issues in English and the transport will be costly. But the bigger problem is the return to rural areas after they may have won a case in court because of either ostracization or the lack of implementation of court rulings against the wishes of traditional leaders. Emotionally the price that they have to pay may be too high.

But if women want to exit the right of exit should be guaranteed in law, which is currently not the case.

\section{Autonomy and Voice}

Autonomy is always related to the liberal subject as part of its capacity as an individual with the right to make decisions. But it is often difficult to distinguish from outside the boundaries of a culture whether women may be choosing certain restrictions or whether they are coerced (Lepinard, (2011: 207). It also implies that women will be able to get a critical distance from their culture and to reflect on their identities. This liberal notion of autonomy has been criticized because it reinscribes the binary between individual rights and groups and that the focus on rationality and self-determination is Western (Lepinard, 2011:20). ${ }^{4}$

Phillips (2009: 104) argues that autonomy may not be the highest good, it is very difficult to think of autonomy outside our cultures. Living in a certain culture may make it difficult to make certain choices because we become autonomous beings through our cultures. Struggles for recognition are not so much struggles for the validation of collective or individual identity but rather for political agency of the group. Recognition is directly related to inclusion and voice. If we think about recognition is this way we can make the political dynamics of exclusion clear.

\footnotetext{
${ }^{4}$ Kymlicka has pleaded for group autonomy to accommodate groups that want to determine their own political fate but it has been widely criticized as unrealistic and will not be discussed here. See eg Kymlicka (1995).
} 
The nature of the injustice that needs to be remedied is political exclusion and the claim for justice is inclusion through voice. Struggles may not be so much about autonomy but about voice - of the excluded, in this regard women living under customary law. The remedy for misrecognition that is needed are strategies for inclusion that will allow groups to rename and change devalued statuses in law, policy and practice (Hobson, 2003:90). This will also have a redistributive effect. Lepinard (2011: 208) argues that in the context of power imbalances the realization of women's autonomy needs specific protection and guarantees.

She suggests a "relational" concept of autonomy rather than a liberal one. Deveaux (in Lepinard, 2011: 210) argues that we need a shift from autonomy to agency because the relationship between identity, culture and social power relations transcend the binary of choice and constraint. Agency will include the individual's sense of self but also in relation to family and community and may allow for action that will take into consideration all these complex relationships. That is why Phillips (2009: 104) argues that autonomy may not be the highest good as often thought of in Western liberal societies. Agency as a minimalist definition of autonomy may show how what looks like coercion may be a choice or forms of agency. This may be a way to start to dislodge the binary between culture and rights.

When we buy into the binary we want the state to be descriptive about rights but if we replace the binary with deliberation and contextualize policy making it may bring solutions for those who feel themselves excluded (Lepinard, 2011: 212). Lepinard suggests that we should go a step further than minimalist agency but move to what she calls "post-agency" which is a more complex understanding of power and the practices of resistance. This will negate the notion of choice as well as the binary logic of consent/subordination (p214- 217), because choice cannot be isolated from the social context and power relations that shape it. This second move would be transformative according to Fraser's model.

Law making under customary law therefore needs to look at how colonial relationship of power have denied the incorporation of living customary law through which women were able to negotiate and deliberate their own relations to land and family as agents. Only by including women in the construction of law can we dislodge the binary of culture and rights.

\section{Dignity, Respect and Hybrid Identities}

Englund argues that the challenges of making relationships and connections the starting point for the politics of recognition are great. His argument is not that there are so many distinct cultures on post-colonial societies that need to be politically accommodated but that the postcolonial subject accommodates multiple identities with a single subject (2004: 14). The challenge to a relational aesthetic of recognition in post-colonial Africa is to acknowledge relations between individuals, groups and minorities crying out for recognition, in a way that will not situate them as subjects in opposition to liberal individual rights.

The post-colonial subject therefore has a hybrid identity and very often is not accorded the necessary respect because of it. Recognition therefore also has to include a dimension of respect and dignity. Where Fraser argues for respect that will flow from changing structural positions, Honneth demands respect that is also mental or attitudinal - it implies conditions of mutual recognition. The elimination of economic inequality and cultural humiliation will also 
require self-respect and being respected by others and this is indeed relational (Honneth, 2004: 351).

In the African context subjects living under customary law are engaged in processes with civil and constitutional law through relations with others. Nhlapo (2000: 147) argues that recognition also requires that we accept that there are conceptions of human dignity that are distinctly African and are involved in cultural practices that may look like subordination from a Western perspective - eg lobola or the bride price is not the selling of women but the uniting of two different families and women feel valued by this. So, the recognition of identities also requires respect for cultural practices.

\section{Legal Pluralism}

The way in which possible conflict of customary law with the Constitution has been dealt with in South Africa is through legal pluralism or a situation where one or more customary justice systems exist alongside formal state justice systems. Two or more parallel but separate legal systems exist with different legal systems using different rules and legal paradigms to decide land (or other) cases (Knight, 2012: 20). These systems often are not reflecting living customary law but a distorted version as a consequence of colonial intervention.

Colonial powers, for example, believed that land was owned collectively overseen by a chief and that the colonial government acted as trustee (rather than reflecting relations of kin with regard to land) (Knight, 2012: 22). In this sense colonial powers made traditional leaders complicit in the distortion of customary law where the definition of the law co-incided with colonial control.

Colonial powers overemphasized the group-based nature of land rights and thereby undermined women's land rights by making them secondary and subordinate to the land rights of men. After decolonization (or post-apartheid) local customary law still functions separately from formal legal systems and serves the same purpose as under colonial rule that of control (Knight, 2010: 23).

When social practices and the legal system are not aligned, law can become viewed not as something that guides and protects their lives but rather a function of state power that discriminates against them (Knight,2010:5). In market societies where the individualization of land claims become the norm customary land rights often come under threat as legal pluralism leaves the rules of the game undefined.

As (Knight, 2012: 23) argues the recognition of customary law is crucial because customary governance systems fill a gap in the administration for poor people who have nowhere to turn. For her the best parts of customary systems should be identified and integrated as part of effective decentralized governance systems. The problem is not that the authenticity of the law is disputed here by those who are viewed as the representatives of people living under customary law, but that it is disputed by those (women) who have no say in what is decided on their behalf.

A further problem with legal pluralism in South Africa is that it creates intra-group inequality by recognizing and entrenching the rights of traditional leaders. Women (and in some cases men) have been excluded from the political and it has created recognition for men in law - the 
creation of a patriarchal pact. So while law reform uses legal pluralism as a solution to claims of rights and justice under customary law, it recognises the rights of men, but misrecognises the status of women as bearers of rights.

The biggest problem of legal pluralism in South Africa is the intra-group misrecognition and lack of equal distribution. It therefore cannot be assumed to solve the problems of misrecognition and redistribution. It is neither affirmative nor transformative as a solution.

\section{The Parity of Participation, Living Customary Law and Relational Autonomy}

The only transformative solution is to combine living customary law with parity of participation for women under relational autonomy.

Living customary law develops as cultures change and come into contact with other cultures. It prevents cultures from becoming static and unchanging. Over time a myriad of practices with regard to land access through different family forms have develop. Women have in many instances been able to negotiate their own positions with regard to law through family councils (that is now not recognised under the TCB). Even men living under customary law have complained that the CLRA and TCB are giving the traditional leaders too much power, creating different tiers of authority that are not customary with regard to African customs and tradition. Living customary law will incorporate women's relations with regard to male relatives as well as kin. It will also encourage negotiation to incorporate the findings of civil courts such as in the Bhe case.

As Claassens and Mnisi (2011: 103) have argued the intersection between custom and rights has been very important for changes at a symbolic level but also in framing the overarching political environment. They argue that a key insight of legal pluralism is that “...in practice, women mix and match claims derived from the overlapping legal and customary regimes of post-colonial society according to whichever best suits their specific interests..."(p103), which is a measure of their agency.

The emerging living law jurisprudence as part of living customary law are very important because struggles over land rights are directly linked to the content of both custom and rights (Claassens and Mnisi, 2011: 103). There is of course always the danger that people living under customary law have internalised the distorted customary law that is deeply embedded in patriarchal values. That is why we should move to "relational autonomy".

MacDonald (2010: 202) argues that rather than rejecting autonomy we should develop relational autonomy that would better meet the requirements of a politically active, public approach to multicultural citizenship. It incorporates the idea of agency of the embedded (contextual) self that I alluded to earlier. Relational autonomy exists within social relationships and is shaped by intersectional identities of race, gender, ethnicity, class and others. Within these relationships people become aware of each other's needs and respond to them. If we think about individual autonomy we think of the independent self/agent but if we think about relational autonomy we think about interdependent beings. As MacDonald (2010: 204) puts it relational autonomy demands a contextual, dynamic conception of agents exercising autonomy - this is a political active account of autonomy. 
But it also needs to be a public autonomy which is dependent on the process law making, interaction, participation and communication (MacDonald, 2010: 205). While MacDonald applies this notion of autonomy to groups, I would argue that it can be applied to both groups (people living under customary law), but also to groups within groups (women living under customary law) and to individuals. Individuals are the members of groups and these members live relationally, especially with regards to living customary law. When relational autonomy is given a public face it also directly brings the political dimension of justice into focus, with a specific reference to accountability. In using relational autonomy the individual accounts for herself, but also holds others to account.

Relational autonomy can account for changing relationships, institutional structures and processes of the political context in which it is exercised (MacDonald, 2010: 206), and is dependent on participation. This will give women participatory parity and will open spaces for them to bring their understanding of living customary law into the public arena. But it will also foster the autonomy of men who can bring their own understanding of customary law to the debates from which a new synthesis of customary practices, especially around land, may emerge, that may take into account issues eg of changing relationships to land in relation to the market.

Relational autonomy will incorporate remedies of injustices of misrecognition of both identity and status (women, living under customary law) as well as injustices of maldistribution. Through the public aspect of relational autonomy the political arena that structures distributive remedies in relation to land (such as the state, the traditional authorities etc) can be held accountable. In this regard people's hybrid identities will be recognised in a relational aesthetic (as suggested by Englund) but it will also show that there is really no separation between politics on a national (constitutional level) and the local level governed through traditional authorities. It will become so much harder to keep the binary of culture/tradition and universal rights in place.

\section{Conclusion}

Through codifying customary law and making patriarchal pacts with traditional leaders the cultures of indigenous African people in South Africa have become reified and this reification has led to injustices related to misrecognition and maldistribution for women.

The way in which the South African government is doing law reform to harmonise customary law with the Constitution has led to a reinforcement of the binary logic of culture and universal rights. It has created a reified notion of culture for people living under customary law by accepting the distorted constructed culture of colonial and apartheid administrations. By using the Communal Land Rights Act, as well as the Traditional Courts Bill as illustrations of the recognition of traditional leadership, I have also shown how it creates intra-cultural inequality by not recognizing women as agents under customary law.

What this paper has shown is that the constructed binary relationship between universal human rights and culture can be dislodged by applying Nancy Fraser's bivalent concept of recognition and redistribution in relation to women's land rights under customary law in South Africa, as a status model and not an identity politics model. The status model shows 
that the lack of recognition of women as agents under customary law leads to maldistribution of land and related benefits.

The incorporation of a political dimension that is irreducible to recognition and distribution has shown that the state and the political is deeply implicated in gender discrimination through the construction of the interpretation of women's land rights and rights of selfrepresentation in traditional courts through the creation of legislation without consulting women about what they want.

A remedy for the status harm induced by these laws is the parity of participation as a preceding condition for recognition and redistribution. This needs to be combined with living customary law. By relying on the development of relational autonomy it will give women living under customary law participatory parity to negotiate their interests (such as access to land) to remedy misrecognition and maldistribution. It will also go a long way towards eradicating intra-group inequality. 


\section{Bibliography}

Brown, W (2006) Regulating Aversion. Princeton: Princeton University Press.

Chanock, M (1995) "Law, State and Culture: Thinking about 'Customary Law" After Apartheid" Acta Juridica. 53.

Chanock, (2000) "'Culture' and Human Rights: Orientalising, Occidentalising and Authenticity" in M Mamdani (ed) Beyond Rights Talk and Culture Talk. South Africa: David Philip.

Claassens, A and S Mnisi (2011) "Rural Women Redefining Land Rights in the Context of Living Customary Law" in B Goldblatt and K McLean (eds) Women's Social and Economic Rights. Cape Town: Juta.

Dahl, H M, P Stolz and R Willig (2004) "Recognition, Redistribtuion and Representation in Capitalist Global Society - An Interview with Nancy Fraser” Acta Sociologica, 47:4, p374382.

Englund, H (2004) "Introduction: Recognizing Identities, Imagining Alternatives" in H Eglund and F J Nyamnjoh (eds) Rights and the Politics of Recognition in Africa. London/New York: Zed, 1-28.

Feldman, L C (2002) "Redistribution, Recogntion, and the State" Political Theory 30:3, 401440.

Fraser, N (2003) "Rethinking Recognition: Overcoming Displacement and Reification in Cultural Politics" in B Hobson (ed) Recogntion Struggles and Social Movements. Cambrigde: Cambridge University Press, p21-32

Fraser, N (2007) "Feminist Politics in the Age of Recognition: A Two Dimensional Approach to Gender Justice" Studies in Social Justice, 1: 1, p23-35

Fraser, N (2000) “Rethinking Recognition” New Left Review, 3 (May’June), p107-120.

Fraser, N (1998a) "Social Justice in the Age of Identity Politics: Redistribution, Recognition and Participation” Discussion Paper FS 98-108 Wissenschaftzentrum Berlin fur Sozialforschung.

Fraser N (1998b) "From Redistribution to Recognition? Dilemmas of Justice in a 'PostSocialist' Age" in C Willett (ed) Theorizing Multiculturalism - A Guide to the Current Debate. Malden: Blackwell in p20-49.

Fraser, N and A Naples (2004) "To Interpret the World and to Change it: An Interview with Nancy Fraser" Signs: Journal of Women in Culture and Society, 29: 4, p1103-1124.

Gouws, A (2004) "The Politics of State Structures: Citizenship and the National Machinery for Women in South Africa" Feminist Africa, 3.

Gouws, A (2011) “Women's Representation in Government: Quotas, Substantive Equality and Self-Interested Politicians" Transformation, 77. 
Gressgard, R (2010) Multicultural Dialogue. New York: Berghahn Books.

Hobson, B (2003) Recognition Struggles and Social Movements. Cambridge: Cambridge University Presss.

Honneth, A (2004) “Recognition and Jusitce” Acta Sociologica, 47:4, p351-364.

Humonga, C (2005) "The Advancement of African Women's Rights in the First Decade of Democracy in South Africa: The Reform of the Customary Law of Marriage and Succession" in C Murray and M O'Sullivan (eds) Advancing Women's Rights. Cape Town: Juta.

Judge, M (2012) "The Culture of the Chiefs is a Set-Back for Gender and Sexual Rights" (http:/queery.oia.co.za/2012/04) (downloaded 20 April 2012).

Knight, R (2010) Statutory Recognition of Customary Land Rights in Africa. FAO

Legislative Study 105. Food and Agricultural Organization (UN). Rome.

Kymlicka, W (1995) Multicultural Citizenship. Oxford: Clarendon Press.

Lepinard, E (2011) “Autonomy and the Crisis of the Feminist Subject: Revisiting Okin's Dilemma" Constellations, 18: 2, 205-221.

Law Race and Gender (LRG) "Submission on the Traditional Courts Bill (B1-2012)" (www.lrg.uct.ac.za)

MacDonald, F (2010) "Relational Group Autonomy: Ethics of Care and the Multiculturalism Paradigm" Hypatia, 25:1, p196-212.

Mamdani, M (1996) Citizen and Subject: Contemporary Africa and the Legacy of Late Colonialism. Princeton: Princeton University Press.

Nhlapo, T (1995) "African Customary Law in the Interim Constitution" in S Liebenberg (ed) The Constitution of South Africa from a Gender Perspective. Cape Town: David Philip.

Nhlapo, T (2000) “The African Customary Law of Marriage and the Rights Conundrum" in M Mamdani (ed) Beyond Rights Talk and Culture Talk. Cape Town: David Philip.

Okin, S M (1999) Is Multiculturalism Bad for Women? Princeton: Princeton University Press. Philips, A (2009) Multi-Culturalism without Culture. Princeton: Princeton University Press. Philips, A and S Saharso (2008) "The Rights of Women and the Crisis of Multiculturalism" Ethnicities, 8:3, pp291-301.

Stopler, G (2007) "Contextualizing Multiculturalism: A Three Dimensional Examination of Multicultural Claims” Law \& Ethics of Human Rights, 1:1, p309-353.

Van der Merwe, W L (1996) "Philosophy and the Multi-Cultural Context of (Post)Apartheid South Africa" Ethical Perspectives 3:1, pp76-90.

Volpp, L (2001) “Feminism versus Multiculturalism” Columbia Law Review, 101: 5, 11811218. 
